\title{
RELIGIÃO E POLÍTICA NO PENSAMENTO DE MAQUIAVEL
}

\author{
José Luiz Ames* \\ profuni2000@yahoo.com.br
}

RESUMO Para Maquiavel, o que confere valor a uma religião não é a importância de seu fundador, o conteúdo dos ensinamentos, a verdade dos dogmas ou a significação dos mistérios e ritos. Importa não a essência da religião e sim sua função e importância para a vida coletiva. A religião ensina a reconhecer e a respeitar as regras políticas a partir do mandamento religioso. Essa norma coletiva pode assumir tanto o aspecto coercivo exterior da disciplina militar ou da autoridade política quanto o caráter persuasivo interior da educação moral e cívica para a produção do consenso coletivo.

Palavras-Chave Maquiavel, Religião, Política, Estado, Poder

ABSTRACT For Machiavelli, religion is valued not by the importance of its founder, the content of its teachings, the truth of its dogmas or the significance of its rites. It is not the essence of what really matters but its function and importance for collective life. Religion teaches to recognize and respect political rules through the religious commandments. This collective norm could assume the outer coercive aspect of the military discipline as well as the inner persuasive character of civic and moral education for the production of collective consensus.

Keywords Machiavelli, Religion, Politics, State, Power

* Professor da Universidade Estadual do Oeste do Paraná - UNIOESTE. Artigo recebido em jan./05 e aprovado em jul./05. 
Maquiavel é conhecido pelo propósito, firmado em $O$ Príncipe, de considerar "mais conveniente seguir a verdade efetiva da coisa do que a imaginação desta" (Il Principe, capítulo XV). Na análise do fenômeno religioso, podemos constatar a utilização deste "método": a religião é examinada a partir de seus efeitos práticos, ou seja, pela capacidade de despertar tanto o medo quanto o amor dos cidadãos a favor do vivere civile. Em outras palavras, "seguir a verdade efetiva da coisa" implica em privilegiar a "causa eficiente". Tratando-se da religião, consiste num determinado procedimento metodológico que analisa esse fenômeno por sua capacidade de cumprir a tarefa cívica de mobilizar os homens a favor do fortalecimento do Estado. Em semelhante modo de considerar as coisas, as questões teológicas perdem importância. Diante disso, como fica o papel da Providência? Pode-se ainda afirmar que ela dirige o destino dos homens? Sustenta-se ainda a convicção cristã de que a marcha dos homens é uma ascensão para Deus? ${ }^{1}$

Tommasini, ${ }^{2}$ numa extensa nota de sua magistral obra sobre a vida de Maquiavel, apresenta a polêmica histórica em torno do pensamento religioso maquiaveliano. As posições, na avaliação deste biógrafo, variam do elogio à condenação: enquanto para alguns, como H. Plato, Maquiavel considerou a religião, sobretudo, como condição indispensável para a manutenção da liberdade, para outros, como C. Cantú, o Secretário da República de Florença foi o fundador da doutrina do Estado ateu que forjou, sobre o modelo grecoromano, a nova civilização, suprimindo Cristo e o Evangelho. Concordamos com Tommasini: o melhor modo de estudar o pensamento religioso de Maquiavel não é o de verificar se foi "cético ou crente, se foi pagão ou cristão, se estava mais próximo da Reforma ou de Loyola, e sim o de ver

1 A novidade da contribuição de Maquiavel, de examinar a realidade humana sob o aspecto particular da vida de um Estado, não escapou à Igreja. Sua obra foi incluída no index, e Maquiavel queimado em efígie. Émile Namer chama a atenção para o fato de que o crime do qual Maquiavel foi acusado, de desprezar a virtude, a religião e tudo o que há de sagrado no mundo, "não era nada em comparação com a sua posição que introduzia a ciência positiva e o determinismo na alma humana, a moral e a religião" (NAMER, É. 1961, p. 91). Segundo ele, afirmar, como o fazia Maquiavel, "que existe um método capaz de prever a ação dos homens e dos Estados, de introduzir a causalidade na ordem espiritual, era contrariar todas as formas, todas as categorias mentais aceitas desde séculos, e não somente estas ou aquelas crenças isoladas" (Ibidem, p. 91). O que a Igreja combatia, na avaliação de Namer, não eram apenas as teses esparsas, hostis à religião e à moral acreditada, mas a maneira nova de compreender o Estado. As autoridades eclesiásticas, pondera o estudioso, "haviam compreendido que o Estado se apresentava cada vez mais como uma entidade que, sem excluir as crenças tradicionais, era autônoma e não aceitava se subordinar a uma autoridade religiosa e estrangeira" (Ibidem, p. 88). Certamente a visão de Émile Namer acerca da obra de Maquiavel, de que este é o introdutor de uma perspectiva científica da política, pode ser questionada sob diferentes pontos de vista. Com efeito, dificilmente os "preceitos" espalhados pela obra de Maquiavel podem ser considerados "leis científicas", pois não se apresentam como regularidades inalteráveis capazes de "prever a ação dos homens e dos Estados". No entanto, podemos conceder-Ihe o acerto na conclusão de que a oposição da Igreja a Maquiavel era devida à possibilidade, aberta pelo florentino, de pensar a existência de um Estado fora de uma estrutura política fundada sobre o catolicismo.

2 TOMMASINI, 1999, v. 2, p. 564, nota 1. 
historicamente, na ordem do movimento e do pensamento religioso, como ele se conduziu, o que pensou, o que fez". ${ }^{1}$

Acatando a sugestão de Tommasini, podemos dizer que, para Maquiavel, não há a menor dúvida de que a origem da religião é puramente humana e possui, como toda instituição, fundadores e chefes. Aliás, e de modo mais preciso, é no ato fundador de uma religião que se revela de modo mais elevado a virtù de um indivíduo: "Entre todos os homens dignos de elogio, os que mais louvor merecem estão os que foram chefes e fundadores das religiões" (Discorsi I, 10). Por ser de origem humana, a religião também está sujeita às leis de nascimento, desenvolvimento e morte que determinam todos os elementos criados: "Nada é mais certo do que o fato de que todas as coisas do mundo têm um termo. (...) Falando de corpos mistos, como repúblicas ou seitas, digo que são salutares aquelas alterações que as reconduzem ao seu princípio" (Discorsi III, 1).

Ainda que não exista ato humano que traga maior glória a alguém do que fundar uma religião, o valor propriamente dito de uma religião, para Maquiavel, não é derivado da fama de seu fundador, do conteúdo dos ensinamentos, da verdade dos dogmas ou da significação dos mistérios e ritos. Numa palavra, daquilo que se costuma chamar "essência da religião". Pelo contrário, a grandeza de uma religião decorre da função e importância que ela exerce em relação à vida coletiva. Ambas, função e importância, são de caráter normativo: a religião ensina a reconhecer e a respeitar as regras políticas a partir do mandamento religioso. Essas normas coletivas podem assumir tanto o aspecto coercivo exterior da disciplina militar ou da autoridade política quanto o caráter persuasivo interior da educação moral e cívica para a produção do consenso coletivo. Como é possível que um mesmo fenômeno obrigue, ao mesmo tempo, externa e internamente? Não estaríamos, aqui, diante de uma contradição no pensamento maquiaveliano? Gennaro Sasso, notando também esse duplo significado da religião, ${ }^{2}$ esclarece que se trata "de um contraste muito mais do que de uma contradição". ${ }^{3}$

Com efeito, a fundação e estabilidade de um Estado dependem da virtù, não apenas do príncipe, mas também do povo. Assim, a dupla função da religião, de coerção e de persuasão, coincide, respectivamente, com a virtù do príncipe e a do povo. A religião, compreendida como instrumentum regni, requer do príncipe a capacidade de servir-se de modo sagaz da fé do povo para levá-lo à obediência da lei civil. Quer dizer, somente um príncipe virtuoso é 
capaz de levar o povo a temer a desobediência às ordens do Estado como se fosse uma ofensa a Deus. E por que o povo estaria mais propenso a obedecer às ordens divinas do que às humanas? Para Maquiavel, isso se deve à superioridade da eficácia do mandamento divino em relação à lei humana para submeter o povo, pois este "teme muito mais romper os juramentos do que as leis por prezar mais o poder de Deus do que o dos homens" (Discorsi I, 11).

No entanto, nenhuma construção política pode ser erigida e mantida unicamente com instrumentos extrínsecos, com base em uma coerção externa tão-somente. Maquiavel chama expressamente a atenção para o fato de que o Estado não pode depender apenas da virtù excepcional de um homem, pois "se um é apto para organizar, não durará muito a coisa organizada se a coloca sobre os ombros de um só" (Discorsi I, 9). É imprescindível, portanto, contar com a virtù do povo para alcançar a estabilidade do Estado. A fé religiosa, compreendida como a vida profunda do povo expressa nos bons costumes e na educação moral e cívica, constitui-se na razão de ser da virtù política dos membros e no fundamento interno do Estado. Vamos proceder, na seqüência, a um exame mais detalhado, com base nos textos da obra de Maquiavel, desses dois distintos significados da religião.

\section{A função de coerção externa da religião ou a submissão ao poder instituído}

Maquiavel introduz o tema da religião, no primeiro livro dos Discorsi, na perspectiva do ordinatore. Isto é, daquele que, se não irá propriamente inventar a religião, tem, contudo, por tarefa estruturá-la e estabelecê-la em preceitos bem visíveis. Foi o que coube a Numa, sucessor de Rômulo:

Embora Roma tenha sido fundada por Rômulo e se reconheça como filhas suas o nascimento e a educação, os céus, julgando que as leis (ordini) de Rômulo não bastavam para tanto império, inspiraram o senado romano para que elegesse Numa Pompílio como sucessor de Rômulo, de modo que as coisas que este deixou de lado foram reguladas por Numa. Este, encontrando um povo ferocíssimo e querendo reduzi-lo à obediência civil com as artes da paz, recorreu à religião como elemento imprescindível para manter a vida civil (civilità) e a constituiu de modo que, por muitos séculos, não havia tanto temor a Deus como naquela república, o que facilitou todos os empreendimentos que o senado ou os grandes homens de Roma planejaram levar a cabo (Discorsi I, 11).

O problema político do sucessor de Rômulo era o de "reduzir" seu povo "à obediência civil". Fazê-lo, porém, com a força que provém da "ferocidade" não apenas resultaria em algo puramente provisório, mas criaria rapidamente um movimento cujo termo final seria a dissolução da sociedade. Isso porque, 
no âmbito de uma coletividade política, a força enquanto tal somente pode ser a da maioria, enquanto a obediência necessária ao vivere civile pode ser devida unicamente a uma minoria. Portanto, para garantir à comunidade política coesão e duração, o fundamento da obediência precisa ser buscado em algo diverso da força.

Isso explica porque Numa, para alcançar seu objetivo (de reduzir à obediência civil um povo ferocíssimo), não tratou o povo no terreno que lhe era próprio enquanto agente do Estado, isto é, o da força, mas compreendeu que precisava voltar-se "às artes da paz". Estas, na passagem da obra maquiaveliana citada acima, não consistem em outra coisa senão na religião, apresentada como o instrumento capaz de subtrair o sentimento da obrigação política do exclusivo domínio da força, e, por isso mesmo, definida "como elemento imprescindível para manter a vida civil". Numa compreendeu, pois, que a força não é o elemento fundamental para levar o povo à obediência, nem a medida das relações internas de um vivere civile. Isso mostra o papel fundamental exercido pela religião para a substituição da força pela civilità.

Em razão de quais artes a religião é capaz desse feito? Maquiavel é claro: religião é timore di Dio. O fundamento da religião para Maquiavel é, pois, o medo de um Deus que, ainda que seja apresentado como algo que tem certa feição humana, considerado em si mesmo não constitui razão de obrigação política e de vínculo social. Contudo, ainda que o medo de um Deus não tenha nada que o faça critério e fundamento de comportamentos políticos e sociais por si mesmo, pode tornar-se tal graças à intervenção prudente de um legislador que saiba alimentar, orientar e, sobretudo, organizar em instituições estáveis esse sentimento humano, tornando-o, assim, apto a suscitar coesão política e obediência civil.

Uma coisa é, portanto, a religião na sua dimensão antropológica, de um misto de medo ancestral e sentimento de inferioridade. Outra coisa é o aspecto da ordem, a constante e visível organização institucional que a prudência do legislador pode dar às necessárias expressões deste mesmo sentimento, trazendo, com isto, benefícios políticos essenciais. Parece evidente que o interesse de Maquiavel está, acima de tudo, na segunda dimensão; ou, pelo menos, se ocupa da primeira somente como fundamento da segunda.

Considerando, pois, que a religião, em seu fundamento, é essencialmente "temor de Deus", de que modo se pode intervir nesse sentimento humano? Como é possível fazer dela a alavanca capaz de produzir comportamentos individuais e coletivos politicamente úteis? São vários os instrumentos referidos por Maquiavel, com destaque à simulação, aos juramentos e aos vaticínios. Examinaremos adiante algumas passagens de utilização desses expedientes. 
Antes disso, porém, vamos aprofundar a análise acerca do comportamento de Numa, na passagem referida acima, para explorar outro aspecto implicado no uso político da religião: o de disfarçar no mandamento religioso a norma política. Constatamos que Numa ocultou seu projeto político, de "reduzir o povo à obediência civil com as artes da paz", no mandamento religioso. Graças à religião, Numa conseguiu fazer com que o povo aceitasse as leis de exceção, com as quais obteve a ordem e a paz.

Mostra-se aqui uma clara diferença entre o príncipe e o povo em relação ao significado do fenômeno religioso: enquanto para o primeiro a religião é um instrumento político, um meio eficiente para submeter os súditos às leis e à obediência, para o povo ela contém um temor sagrado que o faz respeitar os preceitos legais como se fossem mandamentos divinos. $\mathrm{O}$ conhecimento da diferença entre a norma política e o mandamento divino é do domínio unicamente de quem governa. Numa sabia disso e, sagazmente, explorou essa diferença em favor do Estado. A lei civil, quando é apresentada como simples vontade soberana do Estado, tem uma eficácia muito menor do que se aparece como mandamento divino. Por esse motivo, diz Maquiavel: "Nunca houve um legislador que tenha dado leis extraordinárias a um povo e não tenha recorrido a Deus, pois de outro modo não seriam aceitas." (Discorsi I, 11)

Essa concepção, que faz da religião um instrumento de poder e a transforma num meio útil para a ação política, tem levantado contra Maquiavel a crítica de que para ele a religião serve unicamente aos interesses particulares de um príncipe. É um mal-entendido. Temos de admitir, é verdade, como mostrou a passagem acima referida, que Numa se serviu da religião para "manter a vida civil". Isto é, encontrou na religião um recurso conveniente para o fortalecimento do seu domínio. No entanto, Maquiavel louva o uso político da religião apenas na medida em que isso resulta em benefício da coletividade e não da glória pessoal do príncipe. A correção dessa conclusão pode ser verificada no motivo que levou Maquiavel a aprovar a atitude de Numa e dos dirigentes romanos em geral: "Pode ver-se, quem considera bem a história romana, o quanto a religião foi útil para comandar os exércitos, animar o povo, manter os homens bons e envergonhar os maus." (Idem)

Considerada como valor instrumental, a religião é, portanto, um elemento de grande eficácia política. Usada com a devida prudência, constitui uma alternativa ao emprego da força bruta para assegurar a ordem e a paz interna. Oferece um meio para comandar sem recorrer à violência física. Esse recurso é, sobretudo, útil quando os argumentos racionais são impotentes para convencer os homens. É o caso, por exemplo, daquelas coisas “cujas vantagens são conhecidas por um homem prudente, mas que não apresentam em si mesmas razões evidentes que possam persuadir os outros. Por isso, os 
homens sábios, querendo evitar essa dificuldade, recorrem a Deus" (Discorsi I, 11). Em outras palavras, o apelo à força irracional da religião converte-se num meio eficiente para o príncipe convencer o povo da legitimidade de suas ações e da pureza de suas intenções, objetivo que não seria alcançável recorrendo unicamente à razão.

Dessa maneira, a religião se constitui no meio de persuasão privilegiado do qual os governantes podem dispor para fazer com que o povo admita um bem do qual a razão, tão-somente, não bastaria para convencê-lo. É um fenômeno irracional, mais poderoso sobre o espírito do povo do que a própria razão, fenômeno este cuja utilização prudente torna-se a garantia mais segura do êxito do Estado. É isso que motiva o elogio que Maquiavel faz a Numa: "Considerado, portanto, tudo, concluo que a religião introduzida por Numa foi uma das principais causas da felicidade daquela cidade, porque ela produziu boas instituições (ordini); e boas instituições engendraram boa fortuna e da boa fortuna nasceu o feliz êxito de seus empreendimentos" (Discorsi I, 11).

Aqueles que comandam conhecem a influência que o mandamento divino exerce sobre a mente do povo. Para Maquiavel, podem servir-se dessa crença até mesmo quando percebem que se trata de um embuste: "[Os príncipes de uma república ou reino] devem favorecer e acrescentar todas as coisas que surjam a favor dela [religião] ainda que as julguem falsas e o farão tanto mais quanto mais prudentes e mais conhecedores das coisas naturais forem." (Discorsi I, 12) Os dirigentes políticos são sabedores de sua obrigação em relação à coletividade. Eles devem manter o povo unido e obediente ao Estado, pois somente sob esta condição garantem a continuidade da ordem e da paz, que asseguram a vida e a segurança de todos. Como "conhecedores das coisas naturais", são capazes de servir-se dos acidentes favoráveis, isto é, dos aparentes milagres, para fortalecer a crença religiosa e, conseqüentemente, o Estado, sem, contudo, acreditar neles. Assim, quando o dirigente faz parecer uma decisão sua como expressão da vontade divina, deve ser julgado apenas por sua maior ou menor habilidade em conseguir o intento, e não moralmente de ter manipulado as doutrinas religiosas. Tenenti esclarece essa questão alertando que, para o florentino, a religião é a paixão útil mais eficaz que existe para alimentar a força civil e política, mas não um patrimônio de verdade. Entre esta e a religião não há uma medida comum. ${ }^{1}$

Governantes e governados conhecem a verdade da religião de modo diferente. Segundo Gérard Namer, "o príncipe conhece a verdade da religião 
de maneira racional, ao passo que o povo, quando muito, conhece-lhe a falsidade quando a intenção de embuste do mediador lhe é descoberta". ${ }^{1}$ Enquanto aqueles que governam conhecem a verdade da religião por si, os governados a conhecem pela mediação da autoridade dos que governam. Todo segredo está, então, na maneira de interpretar a mensagem divina ao povo. Para o príncipe, ela é sempre apenas útil; para o povo, a religião significa a exteriorização de um mandamento divino.

A passagem da religião como sentimento individual à religião como instrumento indispensável para a ação política é ilustrada por Maquiavel através de uma série de exemplos extraídos da história romana. Em todos eles fica claro que a questão principal não é a da verdade da religião e sim a da interpretação da vontade divina por aqueles que comandam e a favor de seus propósitos. Trata-se aqui de completar o ponto que deixamos em suspenso anteriormente: examinar os expedientes que fazem da religião um instrumento apto para produzir comportamentos individuais e coletivos politicamente úteis. Vamos examinar os que nos parecem essenciais.

Comecemos pela simulação, la finzione: Numa, explica Maquiavel, sentiu que sua autoridade seria insuficiente para "introduzir instituições novas e inusitadas naquela cidade [Roma]". Compreendendo, porém, a importância e a necessidade de tal empreendimento, "simulou ter familiaridade com uma Ninfa, de quem recebia conselhos para serem transmitidos ao povo" (Discorsi I, 11). A fraude, evidentemente, só era do conhecimento de Numa. O povo avaliou a veracidade pelo resultado e este não poderia ser melhor: "Maravilhando-se, pois, o povo romano da bondade e prudência de Numa, cedia ante todas as suas argumentações." (Discorsi I, 11) Não é diferente no caso de Camilo: tendo os soldados romanos saqueado a cidade de Veios, entraram no templo de Juno "sem tumultos, devotos e cheios de reverência" (Discorsi I, 12), e perguntaram à deusa se queria ir com eles para Roma. Como havia quem pensasse ter escutado ela dizer "sim", "lhes parecia ouvir aquela resposta que pressupunham para sua pergunta, opinião e credulidade que foi inteiramente favorecida e acrescentada por Camilo e por outros homens importantes da cidade" (Discorsi I, 12).

Interpretar a atitude simuladora de Numa e Camilo como um simples problema de fraude ou de embuste leva a não compreender a real natureza da questão. O verdadeiro problema não é saber se há ou não algum conteúdo de verdade na religião, e, sim, o de canalizar os sentimentos e as energias que a religião suscita no espírito dos homens numa direção politicamente útil e 
construtiva. Isso justifica a necessidade de esses homens dissimularem o próprio juízo no confronto das coisas que dizem respeito à religião. Igualmente, é o que fundamenta a exigência de fingir uma atitude exatamente oposta, cultivando e protegendo e, na situação concreta, também suscitando tudo quanto seja capaz de favorecer o sentimento religioso coletivo. Podemos até mesmo dizer que os "príncipes de uma república ou reino", como Camilo e Numa, são tanto mais eficazes no cumprimento de suas tarefas em relação à religião quanto mais autônomos a respeito do sentimento religioso eles forem.

Um segundo expediente pode ser observado no modo como os romanos se serviam dos augúrios e oráculos. Encontramos, a esse propósito, uma seqüência de exemplos no capítulo XIII do primeiro livro dos Discorsi. O primeiro refere como a religião se prestou para levar o povo a escolher "todos os novos tribunos dentre os nobres": estes, divulgando que "os deuses estavam irados porque Roma havia usado mal a majestade de seu império" ao escolherem os tribunos somente dentre os plebeus, anunciaram que "não havia outro remédio para aplacar as divindades, senão reduzindo a eleição dos tribunos aos patrícios" (Discorsi I, 13). O povo, "amedrontado pela religião", fez o que lhe foi pedido. O segundo oferece um exemplo do modo "como os capitães dos exércitos se valiam da religião para tê-los [os soldados] dispostos a um empreendimento" (Idem). Cansados por causa do longo sítio à cidade de Veios, os soldados queriam voltar. Foi então que "os romanos inventaram que Apolo e outros oráculos haviam profetizado que a cidade de Veios seria tomada no ano em que as águas do Alba extravasassem suas margens" (Idem). O boato reanimou a tropa que, após um sítio de dez anos, finalmente conquistou a cidade. O terceiro revela o modo pelo qual a nobreza utilizou os "livros sibilinos" para defender-se contra o tribuno Terêntilo e sua lei de limitação do poder dos cônsules interpretando-os de modo a profetizarem "que a cidade corria perigo de perder a liberdade caso houvesse sedição civil” (Idem). O embuste, mesmo descoberto, "não por isso deixou de inspirar tanto terror no peito da plebe, que arrefeceu seu entusiasmo de segui-la" (Idem). A importância do recurso aos augúrios é resumida, finalmente, pelo próprio Maquiavel na abertura do capítulo XIV do primeiro livro dos Discorsi:

Os augúrios não somente eram o fundamento em boa parte da antiga religião dos gentios, como dissemos acima, mas também eram a causa do bem-estar da República romana. Por isso, os romanos lhes prestavam mais atenção do que a qualquer outra coisa e usavam deles nos comícios consulares, ao iniciar um empreendimento, ao enviar os exércitos, ao travar uma batalha, e em toda ação importante, civil ou militar, jamais levaram a efeito uma expedição sem antes persuadir os soldados de que os auspícios lhes prometiam a vitória (Discorsi I, 14). 
Para Maquiavel o problema fundamental não é o da comunicação da vontade divina aos homens. A possibilidade de uma Revelação divina é uma questão teórica da qual Maquiavel não se ocupa explicitamente. É muito provável que, pessoalmente, acreditasse nisso. ${ }^{1}$ Não é isso, porém, o que lhe importa. Trata-se sempre, desde a ótica de quem comanda, de uma interpretação de sinais considerados pelos homens em geral como manifestações da vontade divina. Como esses sinais nunca se manifestam de maneira clara e acessível a todos, é sempre por uma linguagem cifrada que o divino se comunica com o humano, requerendo a mediação de um intérprete. Este faz os sinais significarem aquilo que convém àqueles que comandam. No entanto, Maquiavel condiciona tal utilização a um critério: o resultado deve convergir para um bem coletivo. É esse efeito positivo, reconhecido por todos, o que valida a sua utilização. A exigência, bem compreendido, não é de natureza moral, mas política. Uma interpretação cujo efeito é manifestamente favorável apenas às minorias privilegiadas, ou a algum dirigente no poder, tem por conseqüência o descrédito no oráculo ou nos augúrios. Essa perda da fé na mensagem produz a desordem, que prejudica a continuidade estável da vida do Estado. Essa é a razão pela qual Maquiavel condena semelhante forma de utilização da religião.

O terceiro expediente são os juramentos, dos quais Maquiavel mais vezes recorda o uso, especialmente pelos romanos. É significativo trazer, a esse propósito, o exemplo que Maquiavel extrai de Tito Livio:

Examinando infinitas ações, do povo romano em seu conjunto ou de muitos dos romanos individualmente, se vê como aqueles cidadãos temiam mais romper um juramento do que a lei, como quem estima mais o poder de Deus do que o dos homens, como se vê manifestamente pelos exemplos de Cipião e Mânlio Torquato: porque, depois da derrota que Aníbal havia infligido aos romanos em Cannes, muitos cidadãos haviam se reunido e, desesperando da salvação da pátria, combinaram abandonar a Itália e refugiar-se na Sicília. Inteirando-se disso, Cipião foi buscá-los com a espada desembainhada na mão e os obrigou a jurar que não abandonariam a pátria. Lúcio Mânlio, pai de Tito Mânlio, que logo foi chamado Torquato, havia sido acusado por Marco Pompônio, tribuno da plebe. Antes que chegasse o dia do julgamento, Tito foi buscar Marco e, ameaçando-o de morte se não jurasse retirar a

1 O capítulo LVI do livro I dos Discorsi, a partir do próprio título, leva-nos a considerar seriamente a hipótese de que Maquiavel acreditava na possibilidade de uma Revelação divina: "Os grandes acontecimentos que se produzem numa cidade ou num Estado, são sempre precedidos por sinais que os anunciam e por homens que os predizem". Lista uma série de exemplos antigos e contemporâneos para corroborar a afirmação expressa no título, muito embora faça questão de ressaltar, logo no início do capítulo, que "ignora porque razão" esses fenômenos se produzem. No final do capítulo, ele se justifica dizendo que "para explicar a causa desses prodígios seria preciso ter um conhecimento das coisas naturais e sobrenaturais que eu não tenho". Em todo caso, ainda que admita sua incapacidade de interpretar o porquê desses fenômenos aparentemente de origem divina, confessa: "seja qual for a causa, é certo que sempre estes prodígios foram seguidos de mudanças extraordinárias e inesperadas nos Estados”. 
acusação contra seu pai, obrigou-o a prestar juramento. Este, por respeito ao que havia jurado, retirou a acusação (Discorsi I, 11).

Um outro exemplo bem ilustrativo da eficácia do juramento é o referido no capítulo XIII do primeiro livro dos Discorsi: os tribunos, para forçar a promulgação da lei terêntila, não se opuseram à ocupação do Capitólio por "bandidos e escravos" (Discorsi I, 13). O povo, "convencido por um certo Públio Rubério" de que a reivindicação não era oportuna, jurou "não transgredir a vontade do cônsul" (Discorsi I, 13) e o Capitólio foi tomado pela força. Como o cônsul Públio Valério foi morto no ataque, seu substituto, Tito Valério, entendeu que o juramento permanecia válido. A isso se opuseram os tribunos "dizendo que o juramento havia sido feito ao cônsul falecido" (Discorsi I, 13). O povo, porém, "por temor religioso, preferiu obedecer ao cônsul a seguir os tribunos [...]. Temendo perder toda sua dignidade, os tribunos entraram em acordo com o cônsul, consentindo em obedecê-lo" (Discorsi I, 13).

As passagens nos levam a compreender que, no uso que se faz do juramento, este chega a estabelecer, ainda que por meio de uma involuntária manifestação de responsabilidade da parte do indivíduo, uma poderosa conexão entre o medo íntimo de um Deus e uma obrigação pública de caráter político. Essa é a razão pela qual o juramento é o instrumento por excelência de uso político da religião. Nos exemplos referidos, notamos que a dimensão religiosa, expressa no juramento, é determinante em relação à política. Isso é particularmente verdade no sentido de que, nas situações extremas, a religião, mais do que a política com seus costumeiros instrumentos e sentimentos (as leis, a força, o amor à pátria, a honra), é capaz de constituir-se num âmbito explicativo e motivador de comportamentos individuais e coletivos.

Com efeito, consideremos o exemplo dos cidadãos (a "plebe") que, para defender a pátria, não conseguem encontrar razões, ou mesmo reconhecer a obrigação, no amor pela pátria e suas leis e que, ao invés disso, sentem-se coagidos a isso em virtude de um juramento. Consideremos, igualmente, o caso do tribuno da plebe que, "para obedecer ao juramento feito", esquece a "honra sua" e "o ódio" nos confrontos em relação àqueles que o haviam injuriado. Em suma, nos confrontos entre grandes e plebe, os comportamentos que a própria política não consegue suscitar, os suscita a religião.

Contudo, a dinâmica na qual se produz o juramento torna evidente que aquelas manifestações da religião que vêm em auxílio da política não têm uma origem autônoma, não são um movimento espontâneo e imediato do espírito do povo. Pelo contrário, estas manifestações da religião são o produto de uma 
vontade política bem determinada. ${ }^{1}$ Observando os exemplos citados por Maquiavel, percebemos claramente a dinâmica do juramento: ele não resulta de um ato espontâneo, de uma obrigação coletiva que uma comunidade dá voluntariamente a si própria, mas, muito antes, é sempre o efeito de uma coerção. Cipião constrange os cidadãos a jurarem que não abandonariam a pátria; Tito Mânlio obriga, sob a ameaça das armas, Marco Pompônio a jurar que retiraria a acusação contra seu pai. Cutinelli-Rèndina nota aqui uma circularidade no uso político do juramento religioso: "Considerada na perspectiva do juramento, a relação entre religião e política se revela, então, complexa e, por assim dizer, circular: a política tem necessidade da religião, mas esta religião da qual a política tem necessidade é, por sua vez, um produto da própria prudência política". ${ }^{2}$

No segundo exemplo, o da lei terêntila, aparece claramente que, no uso que a política faz do juramento religioso, se mostra a oposição fundamental presente em toda comunidade política. Revela-se e, ao mesmo tempo, contribui fortemente para mantê-la. A narrativa do episódio é aberta e posteriormente fechada com a indicação do sujeito-fruidor do uso político da religião, que é sempre a nobreza ou a ordem senatorial: "entre os primeiros recursos de que usou a nobreza para remediar a situação estava a religião"; "e assim a religião permitiu que o senado vencesse dificuldades que, sem ela, jamais teriam sido vencidas" (Discorsi I, 13). Nesse episódio, Maquiavel concentra toda sua descrição sobre o juramento extorquido à plebe. Trata-se de um juramento ao qual a plebe romana se sentia presa a tal ponto que preferiu não seguir os próprios representantes, com grave prejuízo para estes últimos: "a plebe, por temor religioso, preferiu obedecer ao cônsul a seguir os tribunos"; "temendo os tribunos perder então toda sua dignidade, puseram-se de acordo com o cônsul para prestar-lhe obediência" (Idem).

O comportamento, nos confrontos dos juramentos, revela uma profunda diferença social. Trata-se de uma diferença que, por vezes, separa o ordinatore, junto com os maiorais dos quais necessita valer-se, de todos os outros; outras vezes, e com maior freqüência, opõe o omore da nobreza ao da plebe. Em todas as situações, e isso é o essencial, divide, e é através dessa divisão que passa a possibilidade de fazer um uso político da religião. Portanto, a sabedoria

1 Segundo Paul Larivaille, isso confirma "a ambigüidade essencial do papel reservado ao povo nas teorias políticas maquiavelianas. Maquiavel teve a intuição da necessidade de uma participação ativa do povo na vida social e política (...). No entanto, está longe de haver extraído dessas premissas todas as implicações que poderiam decorrer logicamente dele. Seu povo não se torna jamais uma força autônoma capaz de uma ação autônoma, mas permanece sempre mais ou menos, tanto nos 'Discursos' como no 'Príncipe', uma massa de manobra para os governantes, uma força, conforme as situações, para reprimir ou para manipular" (LARIVAILLE, 1982, p. 127). 
política requer que essa diferença seja mantida e alimentada. No entanto, e isso é fundamental, a diferença mantida e alimentada pelo uso político da religião não pode aparecer como manipulação dos grandes em favor dos interesses exclusivos destes.

Enquanto a boa interpretação reforça a unidade e eficácia do Estado, a má condena os chefes. O povo suspeita da interpretação quando o príncipe não consegue disfarçar o interesse partidário. Na Roma antiga, quando os oráculos "começaram a falar como os poderosos (a parlare a modo de" potenti), e essa falsidade foi descoberta pelo povo, os homens se tornaram incrédulos e apropriados para perturbar qualquer ordem boa" (Discorsi I, 12). Somente um príncipe corrompido é capaz de acreditar que a autoridade religiosa está inteiramente a seu serviço. Ao reduzir as instituições religiosas à mera fraude a serviço do poder, ele as destrói. Dessa maneira, compromete a própria sobrevivência do Estado, uma vez que, por causa disso, os homens mostram-se "apropriados para perturbar qualquer ordem boa". Ainda que se trate sempre de uma interpretação de sinais tidos como manifestação do divino, a leitura desses sinais jamais pode ser tal que o povo se perceba como um mero instrumento útil a serviço dos poderosos. Quando o discurso e o cerimonial religiosos passam a ser simples expressão do interesse privado, a religião não consegue mais vincular o cidadão ao Estado. O povo pode até continuar submisso, mas já não será mais por um amor cívico e sim pela coação nascida da força das armas ou da ameaça do castigo eterno. Em todo caso, a religião perdeu sua força mobilizadora. A conseqüência inevitável é a decadência do vivere civile.

\section{O caráter de persuasão interna da religião} ou a produção do consenso coletivo

O que fez a grandeza da religiosidade romana, segundo Maquiavel, foi o fato de ela não se restringir ao seu valor meramente instrumental, de uso político preponderantemente a favor dos que comandam. Mais radicalmente ainda, esta função simplesmente não teria sido possível se ela não correspondesse, ao mesmo tempo, a um modo de ser, à natureza de seu povo: se o povo romano se submeteu à ordem política em virtude do mandamento religioso foi porque reconheceu nele um valor. Os legisladores romanos souberam compreender que a religiosidade de um povo é um dado fundamental e inseparável de um conjunto de qualidades, dentre as quais podemos destacar os bons costumes, o devotamento ao bem comum e o amor à pátria, o cumprimento das leis e o respeito sagrado pela autoridade, a coragem dos soldados e a fidelidade dos cidadãos. 
Maquiavel determina de maneira precisa a exemplaridade de Roma, que deve, segundo ele, indicar o caminho de toda ação política, militar e civil. Mas o que significa, precisamente, para Maquiavel, esse retorno ao exemplo romano? Certamente, como havia sido para as gerações precedentes, não renascer com eles, pois a época presente já não era mais percebida como de renascimento, e sim de crise e de decadência. Por isso, essa exemplaridade romana significava, para o florentino, muito antes, encontrar o critério para compreender e criticar mais a fundo a época presente. Desse modo, a questão não é mais a de constatar a diferença entre a maneira romana de fazer política e aquela dos contemporâneos italianos. Trata-se, isto sim, de explicar o como e o porquê de uma tal diferença. $\mathrm{O}$ fundamento e o critério de julgamento que torna isso possível é a religião.

No início do segundo livro dos Discorsi, Maquiavel se propõe a explicar porque o amor à liberdade, que caracterizava os antigos, desapareceu nos modernos. A execução dessa tarefa o leva a uma análise comparada da religião dos antigos e a dos modernos. Em relação a essa comparação, CutinelliRèndina alerta que, "na realidade, o problema que Maquiavel se coloca é o da virtude política e as condições que a desenvolvem e a tornam possível ou que, pelo contrário, a condenam à inércia e, finalmente, ao declínio definitivo"l.

No paralelo que Maquiavel faz, parece ver no cristianismo unicamente vícios e no paganismo apenas virtudes. Primeiro, o cristianismo fazia "estimar pouco as honras mundanas, enquanto o paganismo as tinha como sumo bem, sendo mais arrojado em suas ações" (Discorsi II, 2). Segundo, na liturgia cristã "a pompa é mais delicada do que magnífica" (Discorsi II, 2), enquanto na pagã "não faltava a pompa, nem a magnificência e a elas se acrescentava o ato de sacrifício, cheio de sangue e de ferocidade (...) e este espetáculo, sendo terrível, tornava os homens semelhantes a ele" (Discorsi II, 2). Terceiro, enquanto o paganismo "beatificava unicamente homens cheios de glória mundana, como os capitães de exércitos e os príncipes das repúblicas, (...) o cristianismo glorificou mais os homens contemplativos do que os ativos" (Discorsi II, 2). ${ }^{2}$ Quarto, o cristianismo "colocou o sumo bem na humildade, na abjeção e no desprezo das coisas humanas, enquanto [o paganismo] o punha

UTINELLI-RENDINA, 2004, p. 249

2 Tommasini alerta, a esse propósito, que "a religião antiga, e a romana em especial, não beatificava ninguém. Tratava-se de uma interpretação dos heróis mitológicos, que levou a acreditar que as antigas divindades eram reconhecidas como heróis históricos. (...) O 'beatificare' usado aqui por Maquiavel está, portanto, muito particularmente como reflexo das poucas beatificações do seu tempo, que ele lança sobre a apoteose antiga, quase como contraste" (TOMMASINI, 1999, p. 722). Podemos acrescentar a essa observação de Tommasini que Maquiavel inverte o costume vigente à época: diz que o cristianismo "glorificava" e o paganismo "beatificava". A questão instigante é saber por que faz isso. Muito provavelmente, porque sua intenção é comparar em seu valor religioso, ou, para dizer melhor, pretende comparar à luz de um mesmo critério, o de sua funcionalidade política, cristianismo e paganismo. 
na grandeza de ânimo, na fortaleza corporal e em todas as coisas adequadas para fazer fortes os homens" (Discorsi II, 2). Qual o resultado de semelhante comparação? Segundo Maquiavel, o modo de viver estimulado pelo cristianismo "parece que tornou o mundo fraco, convertendo-o em presa de homens malvados, os quais podem manejá-lo com plena segurança, vendo que a totalidade dos homens, para ir ao paraíso, pensa mais em suportar suas opressões do que em vingar-se delas" (Idem).

Expor as razões do amor que os antigos votavam à liberdade equivale para Maquiavel a explicar porque os modernos perderam esse sentimento. E a causa está na religião, pois os conteúdos desta estão na origem dos diferentes tipos de educação que, por seu turno, constituem o fundamento dos diferentes comportamentos civis, políticos e militares. A diferença na natureza das ações políticas que resultam das duas religiões provém da maneira oposta de considerar as coisas do mundo:

Pensando de onde poderia nascer que, nos tempos antigos, os povos eram mais

amantes da liberdade que neste, creio que procede da mesma causa pela qual os homens atuais são menos fortes, ou seja, da diferença entre nossa educação e a dos antigos, que está fundada na diversidade de ambas as religiões (Idem).

Assim, o critério de distinção entre a virtude dos romanos e a corrupção geral dos modernos reside unicamente na diferente educação e, portanto, nas diferentes religiões existentes entre os antigos e os modernos. A fraqueza dos modernos e a exemplaridade dos antigos têm seu fundamento na diversidade radical de suas religiões e do conteúdo delas. Significa dizer que o mundo moderno tornou-se politicamente impotente por causa de sua religião assim como o mundo antigo havia fundado sua exemplaridade sobre as qualidades específicas da religião que lhe era própria.

Podemos concluir disso, então, que o cristianismo é incompatível com as virtudes próprias do ideal republicano? Seria o caso, talvez, de ressuscitar o paganismo antigo e substituir o cristianismo por ele? Não, não é isso o que Maquiavel pensa, nem sugere. O problema, assegura ele, está na incapacidade dos homens "que interpretaram nossa religião segundo o ócio [a inação] e não segundo a virtù [a ação]" (Idem). O problema está, pois, na maneira como a religião cristã foi ensinada ao longo dos séculos. Ela foi se espiritualizando a ponto de cindir seus propósitos das necessidades mundanas. Se, ao invés disso, "os príncipes das repúblicas cristãs tivessem mantido esta religião tal como foi constituída por seu fundador, estariam os Estados e repúblicas cristãs mais unidos e felizes do que o estão" (Discorsi I, 12). 
Colonna d'Istria notou muito bem que a essência da crítica de Maquiavel à religião foi a de mostrar que "toda religião, também o cristianismo, deve ser julgada em relação com um fim que não é especificamente religioso, mas político: a ligação com a liberdade e o bem comum", ${ }_{1}^{1}$ cuja forma mais elevada é o amor à pátria. É o cristianismo compatível com esse ideal? Se os homens, diz Maquiavel, "se dessem conta de que ela permite a exaltação e a defesa da pátria, veriam que ela quer que a amemos e a honremos e nos preparemos para ser de tal modo que possamos defendê-la" (Discorsi II, 2). Religião alguma pode se opor à defesa da liberdade, nem se conciliar com posições que pleiteiem a renúncia do amor à pátria. A afirmação de que o cristianismo contradiz o destino dos povos e os entrega aos seus inimigos, que poderíamos, de alguma maneira, depreender da passagem citada acima ("A totalidade dos homens, para ir ao paraíso, pensa mais em suportar suas opressões do que em vingar-se delas" - Idem), deve ser interpretada à luz da explicação que o próprio Maquiavel se encarrega de dar na seqüência: "Interpretaram nossa religião segundo o ócio e não segundo a virtù" (Idem).

Ainda que essa explicação possa elucidar a razão pela qual o antigo amor pela liberdade se perdeu, o esclarecimento levanta um novo questionamento: Se a diversidade das religiões e da educação própria a cada uma delas é o que explica o diferente comportamento dos povos em relação à liberdade, como foi possível à religião cristã infiltrar-se no espírito dos altivos povos da Antigüidade, educados no valor da liberdade? Maquiavel apresenta duas respostas distintas a essa questão, uma no capítulo II e outra no capítulo V do segundo livro dos Discorsi.

A resposta avençada por Maquiavel no âmbito do segundo capítulo é simples e clara. O próprio poder romano, ao vencer todos os povos do mundo e privá-los de qualquer liberdade, tornou os espíritos propícios para acolher a esperança ilusória de viver da contemplação do mundo e na expectativa do paraíso. Em outras palavras, o cristianismo pôde infiltrar-se completamente nos povos da Antigüidade, porque Roma, tendo-os conquistado e tornado servos, erradicou da alma deles o amor e o gosto pela liberdade.

Maquiavel oferece uma segunda explicação do triunfo do cristianismo no decurso do capítulo V do segundo livro dos Discorsi. A explicação surge num quadro que parece ter a pretensão de explicar a fundação e existência de qualquer religião e, desse modo, isentar Roma da acusação de haver aberto as portas ao cristianismo e, com isso, extinguindo nos povos o amor à liberdade. O argumento é construído a partir da análise da "regra geral" que determina a sobrevivência das religiões: 
Quando surge uma nova seita, isto é, uma religião nova, sua primeira preocupação, para alcançar reputação, é extinguir a antiga. Quando acontece que os organizadores da nova seita falam uma língua diferente, a extinguem facilmente. Isso se vê claramente observando o comportamento da seita cristã com respeito à pagã, pois anulou todos os seus ordenamentos e cerimônias, e apagou toda lembrança da antiga teologia (Discorsi II, 5).

Com a nova explicação, o cristianismo perde sua especificidade. Como uma religião entre outras, surge e permanece da mesma maneira que qualquer outra religião e possui o mesmo caráter político que caracteriza todas elas. Tem uma origem no tempo e uma duração determinada na história. A religião, não é diferente de qualquer outra instituição humana, segue um movimento comum: nasce, permanece e desaparece segundo lhe é imposto pelo ritmo eterno do cosmos. Nessa perspectiva, não existe mais qualquer diferença entre cristianismo e paganismo. Todas as religiões são iguais, seja quanto à origem, seja quanto à sua finalidade. Bem ao contrário da primeira explicação, o cristianismo não é nem mais nem menos imperfeito do que as outras religiões. ${ }^{1}$

O cristianismo, porém, não aceita esse nivelamento: apresenta-se como religião revelada e, por isso, como a única verdadeira. Isso faz com que o conquistador cristão não queira ser assimilado, nem assimilar. Não quer ser identificado com os homens e povos que submete. Parte simplesmente do pressuposto da superioridade de sua religião sobre qualquer outra. Diferentemente do paganismo romano, que permitia aos povos conquistados a manutenção de suas crenças religiosas, o cristianismo procura impor sua fé por meio de um processo de eliminação dos símbolos religiosos e culturais existentes e sua substituição pelos cristãos. Foi isso que o motivou nas cruzadas contra os muçulmanos. Foi assim que agiu contra os nativos na América espanhola no processo de conquista durante o final do século XV.

1 Cutinelli-Rèndina chama a atenção para o aspecto paradoxal presente nas duas explicações de Maquiavel sobre o triunfo do cristianismo em relação ao problema da imitação dos antigos. Na primeira, apresenta o cristianismo e o paganismo como essencialmente opostos: a fraqueza dos modernos e a exemplaridade dos antigos têm fundamento na diferença radical de suas respectivas religiões e no conteúdo destas. Na segunda, o cristianismo, como "seita" entre as "seitas", nasce, permanece e morre como qualquer "seita". Como a diferença entre as épocas é feita pelas religiões, e como as religiões são idênticas, a diferença entre o antigo e o moderno não tem como ser estabelecida desde o seu fundamento. As duas explicações, entende Cutinelli-Rèndina, revelam-se impróprias para descobrir um ponto de apoio a partir do qual a possibilidade da imitação possa ser fundada de maneira crítica. Na primeira explicação, "Maquiavel escavou um abismo entre o antigo e o moderno e, por isso, tornou a imitação, exatamente por causa do abismo criado pela diferença entre as religiões, impossível". Na segunda explicação, "a relação entre a religião dos antigos e a religião dos modernos se apresenta em termos de substancial identidade. Portanto, na perspectiva do quinto capítulo, a imitação torna-se problemática, se não impossível, mas por uma outra razão, uma vez que se imita o diverso, não o idêntico: como pode, com efeito, constituir objeto de imitação aquilo que é constituído segundo as mesmas leis e age segundo a mesma lógica daquilo que da imitação deve ser o tema?" (CUTINELLI-RÈNDINA, 1998, p. 245). 
Embora a ação substitutiva seja conseqüência inevitável da "regra geral" que determina o nascimento, a permanência e o desaparecimento histórico das religiões, Maquiavel critica essa sanha destruidora do cristianismo. O motivo da censura não é o fato de o cristianismo impor-se às demais religiões. Isso, afinal, é um resultado inevitável do processo histórico ao qual todas as religiões estão submetidas. Maquiavel condena o cristianismo, mais precisamente seus dirigentes, porque esse movimento se nutre do descrédito lançado sobre esse mundo e da vã esperança no além como prêmio. A pietosa crudeltà de Fernando de Aragão, rei da Espanha, "expulsando e espoliando os marranos do seu reino" (Il Príncipe, capítulo XXI), dá a medida exata daquilo que Maquiavel reprova na Igreja, particularmente naqueles que a comandam: sob o pretexto de travar uma guerra santa, pratica as piores atrocidades com o único objetivo de alimentar a ambição política de ampliação de seu domínio. ${ }^{1}$ Essa ambição vem encoberta por um manto de santidade. Por certo, Maquiavel não ignora que, doutrinariamente, o cristianismo desaprova os males da guerra, o amor à violência, a crueldade vingativa, os ódios inexpiáveis, a resistência obstinada dos vencidos e a brutalidade dos vencedores. Contudo, e é isso que Maquiavel não aceita, o cristianismo condena essas práticas não porque são más em si mesmas, e sim porque revelam a vinculação, o apego apaixonado a este mundo. Quando a crueldade é praticada sob o pretexto da salvação da alma imortal, ela não só é justificada, como é até recomendada, acusa o florentino.

Assim, o cristianismo, ao mesmo tempo que condena, também legitima a prática de uma "piedosa crueldade" de tal magnitude que nem os antigos foram capazes de imaginar algo semelhante. À violência e crueldade praticadas pelos antigos por amor à "honra e glória" mundanas, o cristianismo opõe uma violência e crueldade santas, que matam e aterrorizam em nome da vida eterna no céu. Há um evidente uso político da religião cristã. Diferentemente do paganismo antigo, porém, não visa ao bem comum terreno, e sim à salvação eterna de almas imortais. Está nisso a razão principal da reprovação de Maquiavel ao modo de agir dos príncipes cristãos. A diferença tem um agravante: os chefes da religião pagã estavam submetidos às exigências políticas e, no uso que faziam da religião, tinham sempre em vista o bem comum sob pena de sofrerem pessoalmente as punições decorrentes dos tumultos e

1 Diversamente do que sustentamos aqui, para Émile Namer Maquiavel, em O Príncipe, "faz o elogio de Fernando de Aragão, que utilizou a religião para assegurar sua supremacia sobre toda a extensão da Espanha" (NAMER, 1961, p. 126). O argumento de Namer para fundamentar essa conclusão é de que "Maquiavel estimava (...) que o homem de Estado novo deveria favorecer as instituições que condicionavam a unidade social e destruir aquelas que a enfraqueciam. É neste contexto histórico que são julgadas as medidas dolorosas que Fernando de Aragão tomou contra os Marranos" (Idem). 
dissensões que uma falsa interpretação da religião poderia provocar. ${ }^{1}$ Já os chefes da Igreja cristã, recrimina Maquiavel, vivem impunes e se aproveitam das dissensões que eles criam e mantêm, "porque não temem um castigo que não vêem e no qual não acreditam” (Discorsi III, 1).

Maquiavel tem uma idéia muito clara do papel desempenhado pela Igreja Católica na Europa em geral, mas particularmente na Itália. A severa crítica que endereça à Igreja, particularmente aos seus dirigentes mais distintos, pode ser resumida em quatro pontos principais.

Primeiro, o comportamento do clero levou ao enfraquecimento do sentimento religioso na Itália: "Os maus exemplos desta corte [da igreja romana] destruiu na Itália todo sentimento de piedade e de religião, o que tem infinitos inconvenientes e provoca muitas desordens, pois ali onde há religião se supõe todas as virtudes, onde ela falta se deve supor todos os vícios. É, portanto, à Igreja e aos sacerdotes que os italianos devem o fato de viver sem religião e sem moral" (Discorsi I, 12). O agravante, nesse caso, é o fato de o enfraquecimento da fé religiosa ter sido provocado exatamente por aqueles que deveriam ser os primeiros a zelar por ela! Como se comportam os chefes religiosos? Simonia, cupidez, relaxamento dos costumes, toda espécie de abusos em proveito próprio. Francesco Guicciardini, fiel auxiliar dos papas na época, exclama: "Ninguém mais do que eu deplora a ambição, a cupidez e a fraqueza da gente da Igreja". ${ }^{2} \mathrm{O}$ historiador chega a confessar que, não fosse a posição que ocupou junto a diversos papas, teria amado Martinho Lutero unicamente para "ver essa multidão de celerados reduzidos à condição que eles merecem, isto é, ou purgados de seus vícios ou privados de toda a autoridade". ${ }^{3}$

Segundo, o exercício do poder temporal pelos papas provocou a divisão dos Estados italianos. Para saciar sua sede de poder, os papas empregaram métodos de enfraquecimento dos territórios italianos, o que favoreceu os interesses dos estrangeiros. Para assegurar sua supremacia, não hesitaram em chamar em seu auxílio as potências estrangeiras à Itália. No curto período da sua vida pública, Maquiavel assistiu a duas invasões da Itália e uma da Espanha. "Este modo de proceder [...] é o que manteve e continua mantendo desunida a Itália" (Istorie Fiorentine I, 9), conclui o florentino.

Terceiro, a sede de poder dos papas levou à ruína moral da Igreja na Itália. No entendimento de Maquiavel, "temos a prova mais marcante desta decadência

1 É o que Maquiavel ilustra com o exemplo de Ápio Pulcro: ele "querendo lutar contra o exército cartaginês, mandou consultar as aves sagradas e, contando-lhe que as aves não haviam comido, disse: 'vejamos se querem beber', e os fez lançar ao mar. Começada a batalha, foi derrotado, pelo que foi condenado em Roma, enquanto Papírio [que também interpretara os auspícios 'segundo a necessidade', mas tivera êxito] foi homenageado" (Discorsi I, 14).

2 GUICCIARDINI, 1995, n. 28.

3 Idem. 
no fato de que os povos mais próximos da Igreja Romana, a capital da nossa religião, são justamente os menos religiosos" (Discorsi I, 12). Maquiavel deplora que os papas não se restrinjam à sua missão espiritual, tal como no princípio do cristianismo: "Os sucessores de São Pedro eram reverenciados pela santidade de suas vidas e milagres; o exemplo que deram ampliou tanto a religião cristã que a ela os príncipes tiveram de obedecer para acabar com tanta confusão que havia no mundo" (Istorie Fiorentine I, 9). Tivessem os papas se limitado à sua missão espiritual, teriam evitado a ruína moral na qual a Itália se encontra.

Quarto, a Igreja é o principal obstáculo à unificação da Itália: “Um país não pode estar unido e feliz se todo ele não estiver submetido à obediência de uma república ou um príncipe, como sucedeu na França e na Espanha. E a causa porque a Itália não chegou à mesma situação, e não tenha nem uma república ou príncipe que a governe, é unicamente da Igreja" (Discorsi I, 12). Maquiavel acusa o Papa de ser demasiado fraco para liderar a unificação dos Estados italianos, mas, ao mesmo tempo, suficientemente forte para impedir que outro o faça (Idem).

Maquiavel, seguindo os passos que Marsílio dera dois séculos antes, mostra que o exercício do poder temporal pela Igreja corrompe sua missão espiritual. A religião cumpre uma função essencial na estrutura social. É dela que provém a coesão interna do povo e o devotamento à pátria como a um mandamento religioso. A fé religiosa inspira o amor cívico e cultiva a virtù coletiva sem a qual nenhum Estado sobrevive. Os chefes da Igreja, quando se imiscuem na vida do Estado, destroem o sentido espiritual identitário que funde o povo numa nação. O poder exercido pela autoridade religiosa, devido ao seu caráter divisionista, leva o povo a descrer. Paradoxalmente, portanto, a luta do Estado contra a Igreja, travada por muitos príncipes na época, era, no fundo, um modo de defender a religião contra a Igreja. Uma Igreja secularizada perde a função que lhe cabe no universo político maquiaveliano. Além de esvaziar o sentimento religioso do povo, um papa sequioso de poder temporal arriscava provocar a reação dos Estados colocando em perigo a vida das populações.

Maquiavel pensa que o cristianismo tomou aos olhos de muitos crentes o sentido exclusivo de resignação ao sofrimento terrestre, de renúncia à luta humana e social. Esse sentido se opõe frontalmente à virtude cívica, que deve encontrar na religião uma fonte de inspiração para a exaltação do serviço à pátria. O que fazer para regenerar a fé cristã? Como agir para recobrar o primitivo vigor? De que maneira "os príncipes das repúblicas cristãs" devem se comportar para que a religião cristã volte a ser "tal como foi constituída por seu fundador" (Idem)? 
Maquiavel é do entendimento de que o caminho que a religião deve seguir é o mesmo que o das demais instituições, como, por exemplo, os Estados. Todos os "corpos mistos" devem ser periodicamente reconduzidos àquela condição originária que constitui a razão de sua existência: "Para querer que uma seita ou uma república viva longamente, é necessário retornar freqüentemente para o seu princípio" (Discorsi III, 1), ensina Maquiavel. O que há no princípio das instituições que possui essa força de renová-las? Maquiavel responde: "Em todos os princípios das seitas, das repúblicas e dos reinos existe forçosamente alguma bondade, graças à qual recobrarão sua primitiva reputação e sua capacidade de crescimento" (Idem).

Em relação às religiões, especificamente, o bom efeito dessa prática pode ser comprovado, segundo Maquiavel, através dos exemplos de São Francisco e São Domingos:

Quanto às seitas, vemos quão necessário é que exista nelas essa renovação, por exemplo, de nossa religião. Esta, se não tivesse retornado às suas origens graças a São Francisco e São Domingos, teria sido completamente extinta. Estes, com a pobreza e com o exemplo da vida de Cristo, a despertaram na mente dos homens, onde já estava esquecida. Suas novas ordens (ordini nuovi) foram tão poderosas que, graças a elas, a desonestidade dos prelados e dos chefes da Igreja não conseguiram arruiná-la. (...) Essa renovação, portanto, manteve e mantém esta religião" (Discorsi III, 1).

A necessidade de retornar ao princípio é uma exigência inevitável que brota da natureza histórica da instituição religiosa. As religiões, assim como os Estados, estão submetidas à lei inelutável da geração e da corrupção. O cristianismo sobreviveu ao longo dos séculos, porque soube "retornar às suas origens" renovando as bases sobre as quais está assentado. ${ }^{1}$

Maquiavel extrai dessa origem histórica das religiões duas conseqüências que evidenciam sua compreensão da finalidade da religião. Primeiro, que é vã a oposição entre religião revelada (cristã) e não-revelada (pagã). Segundo, que é absurda a idéia de uma Providência divina reguladora das coisas mundanas. A primeira conseqüência permite-lhe sustentar a função política da religião: por ser criação humana e não divina, a religião deve ser julgada por sua eficácia em relação ao cumprimento de finalidades mundanas, particularmente a de desenvolver o "amor à pátria" (Discorsi II, 2). A segunda conseqüência possibilita-lhe evidenciar a sua tese da determinação humana (ainda que não de modo absoluto) dos acontecimentos históricos: contra as interpretações fatalistas,

1 Werner Kaegi, embora reconheça que o coração de Maquiavel pertenceu ao Estado e não à Igreja, observa que "um homem que fala dessa maneira não é um inimigo da vida católica, nem do cristianismo em geral, e sim pertence, como figura periférica, àquele grupo através de cujas idéias o catolicismo, nas décadas seguintes, será submetido à profunda renovação e transformação também na Itália" (KAEGI, 1942, p. 97). 
que querem atribuir as calamidades e as adversidades em geral à fortuna ou a Deus, Maquiavel afirma o papel decisivo da virtù denunciando a fé numa Providência reguladora como fuga, desleixo e incapacidade política.

\section{Referências Bibliográficas}

COLONNA d'ISTRIA, Gérard. L'Art politique chez Machiavel. Paris: Vrin, 1980.

CUTINELLI-RÈNDINA, Emanuele. Chiesa e religione in Machiavelli. Pisa; Roma: Instituti Editoriale e Poligrafici Internazionali, 1998.

. Mythe de l'ancien et perception du moderne chez Machiavel. Astérion, n. 2, juil. 2004.

GUICCIARDINI, Francesco. Ricordi. São Paulo: Hucitec, 1995.

KAEGI, Werner. Historische Meditationen. Zurich: [s.n.], 1942.

LARIVAILLE, Paul. La pensée politique de Machiavel. Nancy: Presses Universitaires de Nancy, 1982.

MACHIAVELLI, Niccolò. Discorsi sopra la prima deca di Tito Livio. In: MARTELLI, Mario (Ed.). Tutte le Opere. Firenze: Sansoni, 1992. p. 73-254.

. Il Principe. In: MARTELLI, Mario (Ed.). Tutte le Opere. Firenze: Sansoni, 1992. p. $255-98$

. Istorie Fiorentine. In: MARTELLI, Mario (Ed.). Tutte le Opere. Firenze:

Sansoni, 1992. p. 629-844.

NAMER, Émile. Machiavel. Paris: PUF, 1961.

NAMER, Gérard. Maquiavel ou as origens da sociologia do conhecimento. São Paulo: Cultrix, 1982.

SASSO, Gennaro. Niccolò Machiavelli: storia de suo pensiero político. Bolonha: Il Mulino, 1980.

TENENTI, Alberto. La religione di Machiavelli. Studis Storici, anno X, 1969. TOMMASINI, Oreste. La vita e gli scritti di Niccolò Machiavelli nela loro relazione col machiavellismo. Bolonha: Il Mulino, 1999. v. 2. Primeira Parte. 